\title{
Protection of Primary Cultured Mouse Hepatocytes from Chemical Hypoxia- induced Injury by Hydrogen Sulfide
}

Min Young Lee*

\section{Department of Molecular Physiology, College of Pharmacy, Kyungpook National University, Daegu 702-701, Korea}

Received August 26, 2013 /Revised October 7, 2013 /Accepted October 14, 2013

\begin{abstract}
We examined the effect of hydrogen sulfide $\left(\mathrm{H}_{2} \mathrm{~S}\right)$ in chemical hypoxia-induced injury in mouse hepatocytes. Cell viability was significantly decreased by cobalt chloride $\left(\mathrm{CoCl}_{2}\right)$, a well-known hypoxia mimetic agent in a time- and dose- dependent manner. Sodium hydrosulfide (NaHS, a donor of $\mathrm{H}_{2} \mathrm{~S}$ ) pretreatment before exposure to $\mathrm{CoCl}_{2}$ significantly attenuated the $\mathrm{CoCl}_{2}$-induced decrease of cell viability. $\mathrm{CoCl}_{2}$ treatment resulted in an increase of intracellular ROS generation, which is inhibited by NaHS or $N$-acetyl-cysteine (NAC, a ROS scavenger), and p38 MAPK phosphorylation, which is also blocked by $\mathrm{NaHS}$ or NAC. The $\mathrm{CoCl}_{2}$-induced increase of the Bax/Bcl-2 ratio was attenuated by NaHS, NAC, and SB 203580 (p38 MAPK inhibitor). The $\mathrm{CoCl}_{2}$-induced decrease of cell viability was also attenuated by NaHS, NAC, and SB 203580 pretreatment. Additionally, NaHS inhibited the $\mathrm{CoCl}_{2}$-induced COX-2. Similar to the effect of NaHS, NAC blocked $\mathrm{CoCl}_{2}$-induced COX-2 expression. Furthermore, NS-398 (a selective COX-2 inhibitor) attenuated not only the $\mathrm{CoCl}_{2}$-induced increase of the $\mathrm{Bax} / \mathrm{Bcl}-2$ ratio, it also decreased cell viability. Taken together, $\mathrm{H}_{2} \mathrm{~S}$ protects primary cultured mouse hepatocytes against $\mathrm{CoCl}_{2}$-induced cell injury through inhibition of the ROS-activated p38 MAPK cascade and the COX-2 pathway.
\end{abstract}

Key words : Hydrogen sulfide, cobalt chloride, chemical hypoxia, mouse hepatocytes

\section{Introduction}

Hydrogen sulfide $\left(\mathrm{H}_{2} \mathrm{~S}\right)$, an endogenous gaseous mediator, is produced by pyridoxal-5'-phosphate-dependent enzymes, including cystathionine- $\gamma$-lyase, cystathionine- $\beta$ synthase and 3-mercaptopyruvate sulfurtransferase, during cysteine metabolism $[6,46] . \mathrm{H}_{2} \mathrm{~S}$ was known as a toxic gaseous material, but it is now a signaling gasotransmitter, which exerts physiological or pathological roles both in vivo and in vitro $[36,53] . \mathrm{H}_{2} \mathrm{~S}$ promotes vascular smooth muscle relaxation and induces vasodilation of isolated blood vessels $[9,32]$. It has been also evident that $\mathrm{H}_{2} \mathrm{~S}$ exerts their role as a potent antioxidant $[27,60]$. Additionally, previous studies show that $\mathrm{H}_{2} \mathrm{~S}$ shows a protective role against various stimuli-triggered injuries in many organs including heart, kidney and so forth $[3,49]$. However, the mechanisms of $\mathrm{H}_{2} \mathrm{~S}$ attenuated hepatic ischemic injury remains to be elucidated.

\footnotetext{
*Corresponding author

Tel : +82-53-950-8577, Fax : +82-53-950-8557

E-mail : vetmedic@knu.ac.kr

This is an Open-Access article distributed under the terms of the Creative Commons Attribution Non-Commercial License (http://creativecommons.org/licenses/by-nc/3.0) which permits unrestricted non-commercial use, distribution, and reproduction in any medium, provided the original work is properly cited.
}

Hepatic tissue is quite vulnerable to hypoxic injury compared with other organs [34]. In general, hypoxia generates reactive oxygen species (ROS) and excessive ROS generation is known to cause oxidative damage to DNA, lipids and proteins $[5,52]$. This results in hypoxic cell injury, which is mediated by ROS-induced intracellular signaling molecules, including mitogen-activated protein kinases (MAPKs) [10]. MAPKs participate in varioius cellular functions such as cell proliferation, cell differentiation, cell motility, and cell death [37]. There are three major MAPK family subgroups: extracellular signal-regulated kinase 1/2 (ERK 1/2), c-Jun $N$ terminal of stress-activated protein kinase (JNK), and p38 protein kinase. Especially, signal cascade involving p38 MAPK, activated by extracellular stress signals, are involved in cell differentiation and death and is known to be activated by a variety of environmental stresses or chemicals [40,55]. Previously, it was reported that $\mathrm{CoCl}_{2}$ activates p38 MAPK, which is involved in $\mathrm{CoCl}_{2}$-induced apoptosis in other cell types [65]. These findings suggest that ROS-induced p38 MAPK can be involved in $\mathrm{CoCl}_{2}$-induced hepatic injury. It has also been reported that ROS can stimulate cyclooxygenase (COX)-2 expression in $\mathrm{CoCl}_{2}$-induced chemical hypoxic condition $[56,58]$. At present, at least two COX isoenzymes, COX-1 and COX-2, have been identified [59]. 
COX-1 is usually expressed constitutively, whereas COX-2 remains undetectable in most tissues in the physiological state but rapidly accumulates under pathological conditions [11]. The roles of COX-2 overexpression are complicated and ambivalent in different models, mediating either cytotoxicity or cytoprotection $[4,7,21,28,50,62]$. Some studies indicated that inhibition of COX-2 activation attenuated ischemic hepatic injury [21] while other reports showed that during ischemic cardiotoxicity, overexpression of COX-2 play its protective role $[4,28]$.

In the present study, we investigated the cytoprotective effect of $\mathrm{H}_{2} \mathrm{~S}$ in primary cultured mouse hepatocytes treated with cobalt chloride $\left(\mathrm{CoCl}_{2}\right)$, a widely used hypoxia mimetic agent that promotes the accumulation of hypoxia-inducible factor-1 a (HIF-1a), a critical regulator for the cellular response to hypoxia [18], and induces oxidative stress [23, 64] and apoptosis in various cells [26, 64]. Therefore, this study assessed the effect of $\mathrm{H}_{2} \mathrm{~S}$ on hypoxic cellular injury induced by $\mathrm{CoCl}_{2}$ and its associated mechanisms in primary cultured mouse hepatocytes.

\section{Materials and Methods}

\section{Materials}

Eight-week-old male ICR mice were purchased from Daehan Bio Link Co. (Incheon, Korea). All animal management procedures were conducted in accordance with the standard operation protocols established by Kyungpook National University. Cell Counting Kit-8 (CCK-8) was purchased from Dojindo Laboratories (Japan). $\mathrm{CoCl}_{2}, \mathrm{~N}$-acetyl-1-cysteine, SB 203580, and type IV collagenase were obtained from Sigma-Aldrich (St. Louis, USA). The 5-(and 6)-chloromethyl-2', $7^{\prime}$-dichlorodihydrofluorescein diacetate, acetyl ester (CM-H2DCFDA) were purchased from Life Technologies (Grand Island, USA). Fetal bovine serum (FBS) was acquired from Thermo scientific (USA). The phosphop38 MAPK antibodies were obtained from New England Biolabs (Hertfordshire, UK). The HIF-1a, Bcl-2, caspase-3, COX-1, COX-2, goat anti-rabbit IgG, and goat anti-mouse IgG antibodies were supplied by Santa Cruz Biotechnology (Santa Cruz, USA).

\section{Isolation of mouse hepatocytes}

Primary mouse hepatocytes were isolated from mouse liver using the two-step EDTA and collagenase perfusion method. After the mouse was anesthetized, the liver was perfused with Krebs-Henseleit buffer without $\mathrm{Ca}^{2+}$ and $\mathrm{SO}_{4}{ }^{2-}$ $(115 \mathrm{mM} \mathrm{NaCl}, 25 \mathrm{mM} \mathrm{NaHCO}, 5.9 \mathrm{mM} \mathrm{KCl}, 1.18 \mathrm{mM}$ $\mathrm{MgCl}_{2}, 1.23 \mathrm{mM} \mathrm{NaH} \mathrm{PO}_{4}, 6 \mathrm{mM}$ glucose, $0.1 \mathrm{mM}$ EDTA) through the hepatic portal vein to rinse the blood out (flow: at $7 \sim 9 \mathrm{ml} / \mathrm{min}$ for $5 \mathrm{~min}$ ). Then, the liver was perfused with Krebs-Henseleit buffer without $\mathrm{Ca}^{2+}$ and $\mathrm{SO}_{4}^{2-}$ containing $0.02 \%$ collagenase and $0.1 \mathrm{mM} \mathrm{CaCl}_{2}$ until the liver appeared soft. The liver was then removed and gently minced, and the obtained cells were dispersed in medium (DMEM; Life Technologies, NY, USA) containing $10 \%$ FBS and $1 \%$ penicillin/streptomycin (Life Technologies, NY, USA). The solution containing the mixed cells and debris was filtered through a $100-\mu \mathrm{m}$ filter. Subsequently, the filtrate was centrifuged at $50 \mathrm{~g}$ for $3 \mathrm{~min}$ at $4^{\circ} \mathrm{C}$; the cells were washed with DMEM three times and then seeded in collagen-coated plates. The cells were maintained in DMEM high glucose (4.5 g/l) supplemented with 10\% FBS, 1\% penicillin/streptomycin, $1 \mathrm{\mu g} / \mathrm{ml}$ insulin, and $10^{-12} \mathrm{M}$ dexamethasone for $24 \mathrm{~h}$ at $37^{\circ} \mathrm{C}$ in a humidified atmosphere $\left(5 \% \mathrm{CO}_{2}\right)$. The cells were incubated with fresh Williams' $\mathrm{E}$ medium without FBS $24 \mathrm{~h}$ prior to the experiments.

\section{Cell viability assay}

Cell viability was detected using CCK-8 assay system. Mouse hepatocytes were cultured in 96-well plates with three triplicate wells in each group. The cells were treated with conditioned medium as indicated. The CCK- 8 solution was added to each well at a 1:10 dilution followed by further incubation at $37^{\circ} \mathrm{C}$ for $3 \mathrm{~h}$. Absorbance was measured at 450 $\mathrm{nm}$ using a microplate reader (BioTek Instruments, Inc., VT, USA). All values are expressed as the mean ( \pm standard error, SE) of triplicate experiments. The values were converted from absolute counts to a percentage of the control.

\section{Western blot analysis}

The cell homogenates ( $30 \mu \mathrm{g}$ of protein) were separated using $10 \%$ or $12 \%$ SDS-polyacrylamide gel electrophoresis and then transferred to polyvinylidene fluoride (PVDF) transfer membranes. The blots were then washed with Tris-buffered solution containing Tween-20 (TBST, $10 \mathrm{mM}$ Tris- $\mathrm{HCl}$ (pH 7.6), $150 \mathrm{mM} \mathrm{NaCl}, 0.1 \%$ Tween-20), blocked with $5 \%$ skimmed milk powder in TBST for $1 \mathrm{~h}$, and incubated for $12 \mathrm{~h}$ with the appropriate primary antibody at the dilutions as recommended by the supplier $(1: 1,000)$. The membranes were then washed with TBST and incubated with horseradish peroxidase-conjugated secondary antibody 

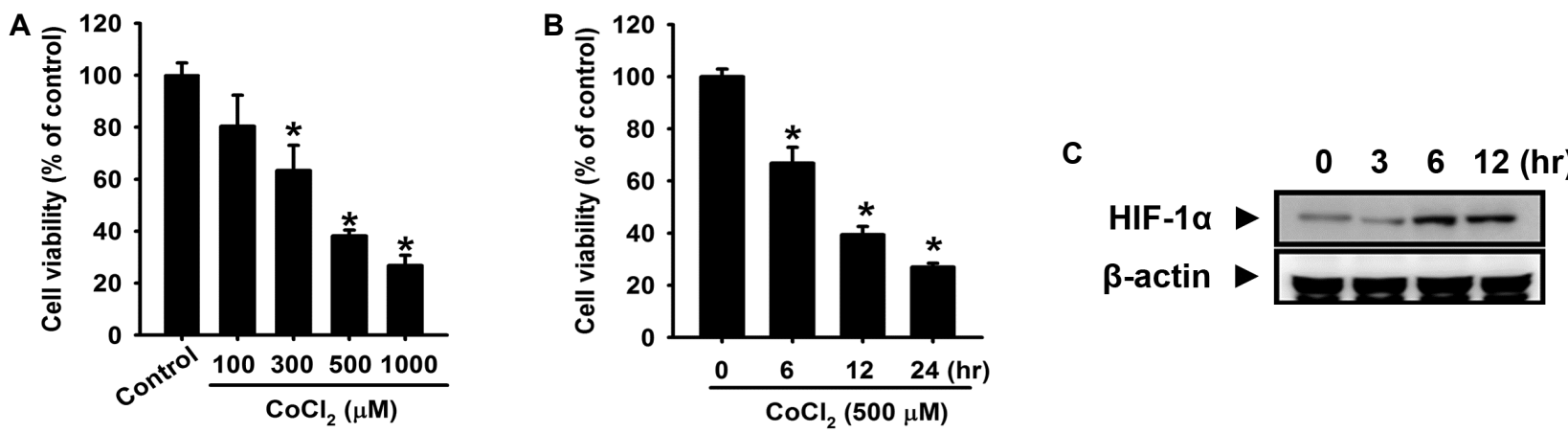

Fig. 1. Effect of $\mathrm{CoCl}_{2}$ in cell viability in primary cultured mouse hepatocytes. (A) Mouse hepatocytes were incubated with $\mathrm{CoCl} \mathrm{C}_{2}$ at indicated concentrations for $12 \mathrm{~h}$. (B) Cells were incubated with $500 \mu \mathrm{M} \mathrm{CoCl}_{2}$ for various times $(0-24 \mathrm{~h})$. Cell viability was measured by CCK-8 assay. (C) Cells were incubated for various times (0-12 h), and the level of cellular HIF-1a expression was detected through western blotting. The values are expressed as the mean $\pm \mathrm{SE}$ of three independent experiments with triplicate dishes. ${ }^{*} p<0.05$ vs. control.

$(1: 5,000)$ for $12 \mathrm{~h}$. The bands were visualized using an enhanced chemiluminescence detection system (Thermo Scientific, USA) according to the manufacturer's protocols.

\section{Detection of intracellular ROS}

$\mathrm{CM}-\mathrm{H}_{2}$ DCFDA (DCF-DA), which functions as a ROS-sensitive fluorophore, was used to detect the intracellular ROS. The cells were plated on 35-mm cell culture dishes and incubated under the conditions as described previously. The cells were then kept in the dark and treated with $5 \mu \mathrm{M}$ DCF-DA for $30 \mathrm{~min}$ at $37^{\circ} \mathrm{C}$. After all the treatments were completed, the cells were washed three times with PBS and were imaged using fluorescence microscopy (100×; DM IL LED Fluo, Leica, Germany).

\section{Statistical analysis}

The results are expressed as the mean $\pm \mathrm{SE}$. The difference between the two mean values was analyzed by Student's t test. A $P$ value of $<0.05$ was considered significant.

\section{Results}

$\mathrm{H}_{2} \mathrm{~S}$ inhibits $\mathrm{CoCl}_{2}$-induced cytotoxicity in primary cultured mouse hepatocytes

To investigate the effect of $\mathrm{CoCl}_{2}$, the level of cell viability was examined with the CCK-8 assay system. As shown in Fig. $1 \mathrm{~A}, \mathrm{CoCl}_{2}$ significantly decreased the level of cell viability in a time-dependent manner. Fig. 1B shows that treatment of $\mathrm{CoCl}_{2}$ to mouse hepatocytes at concentrations ranging from 100 to $1,000 \mu \mathrm{M}$ for $12 \mathrm{~h}$ led to a decrease in cell viability in a dose-dependent manner. Additionally, the effect of $\mathrm{CoCl}_{2}$ treatment on the level of hypoxia-inducible fac- tor-1a (HIF-1a) expression was analyzed in order to verify whether the hypoxic cell responses were induced by $\mathrm{CoCl}_{2}$. The expression of HIF-1a was increased in a time-dependent manner (Fig. 1C). To determine the effect of hydeogen sulfide $\left(\mathrm{H}_{2} \mathrm{~S}\right)$ on $\mathrm{CoCl}_{2}$-induced cell injury, cells were pretreated with various concentrations of sodium hydrosulfide (NaHS, a donor of $\mathrm{H}_{2} \mathrm{~S}$ ) for $30 \mathrm{~min}$ and then treated with $500 \mu \mathrm{M}$ $\mathrm{CoCl}_{2}$. NaHS significantly attenuated the decreased cell viability and these results indicate that NaHS pretreatment protects against $\mathrm{CoCl}_{2}$-induced hypoxic cell injury in primary cultured mouse hepatocytes (Fig. 2).

Effect of $\mathrm{H}_{2} \mathrm{~S}$ on $\mathrm{CoCl}_{2}$-induced oxidative stress and p38 MAPK in primary cultured mouse hepatocytes

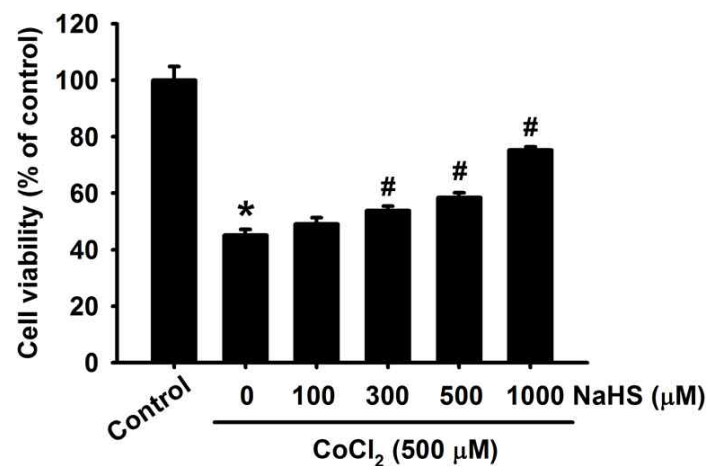

Fig. 2. Effect of $\mathrm{H}_{2} \mathrm{~S}$ on $\mathrm{CoCl}_{2}$-elicited cytotoxicity. Mouse hepatocytes were incubated with $500 \mu \mathrm{M} \mathrm{CoCl}_{2}$ for $12 \mathrm{~h}$ in the absence or presence of pretreatment with $\mathrm{NaHS}$ at the indicated concentrations for $30 \mathrm{~min}$. Cell viability was measured by CCK-8 assay. The values are expressed as the mean $\pm \mathrm{SE}$ of three independent experiments with triplicate dishes. ${ }^{*} p<0.05$ vs. control, ${ }^{\#} p<0.05$ vs. $\mathrm{CoCl}_{2}$ only. 
In order to determine whether the $\mathrm{H}_{2} \mathrm{~S}$-induced protective effect was associated with its antioxidation in $\mathrm{CoCl}_{2}$-treated mouse hepatocytes, intracellular reactive oxygen species (ROS) levels were observed. As shown in Fig. $3 \mathrm{~A}, \mathrm{CoCl}_{2}-$ increased ROS were attenuated by NaHS $(1,000 \mu \mathrm{M})$ or $N$-acetyl cysteine (NAC), a common ROS scavenger $(1,000$ $\mu \mathrm{M})$. In addition, the signaling molecule associated with $\mathrm{CoCl}_{2}$-induced cell injury, p38 MAPK, was elevated. The maximum level of p38 MAPK activation was observed at 90-120 min after treatment with $\mathrm{CoCl}_{2}$ (Fig. 2B), and $\mathrm{NaHS}$ and NAC attenuated $\mathrm{CoCl}_{2}$-induced phosphorylation of p38 MAPK (Fig. 3C). Furthermore, we observed that pretreatment with NaHS, NAC, and SB 203580 (p38 MAPK inhibitor, $1 \mu \mathrm{M}$ ) obviously attenuated the $\mathrm{CoCl}_{2}$-induced decrease of Bcl-2 expression and increase of Bax expression. Additionally, increase of $\mathrm{Bax} / \mathrm{Bcl}-2$ ratio by $\mathrm{CoCl}_{2}$ treatment was significantly decreased by NaHS, NAC and SB 203580 (Fig. 3D). Consistent with these results, decreased cell viability induced by $\mathrm{CoCl}_{2}$ treatment was partially recovered by pretreatment with NaHS, NAC, and SB 203580 (Fig. 3E).

A

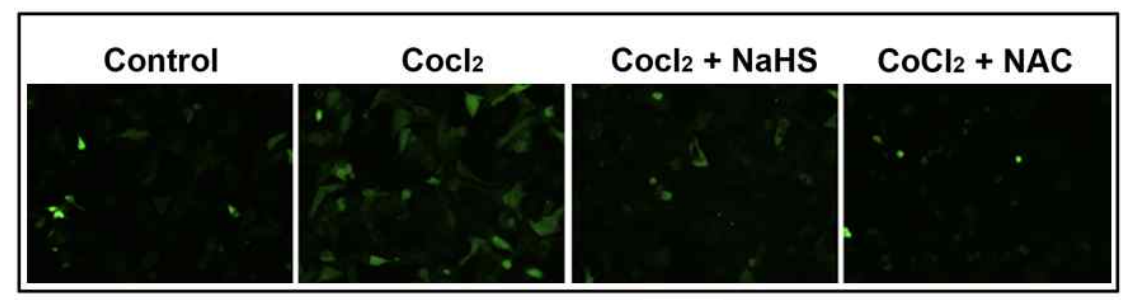

B

C
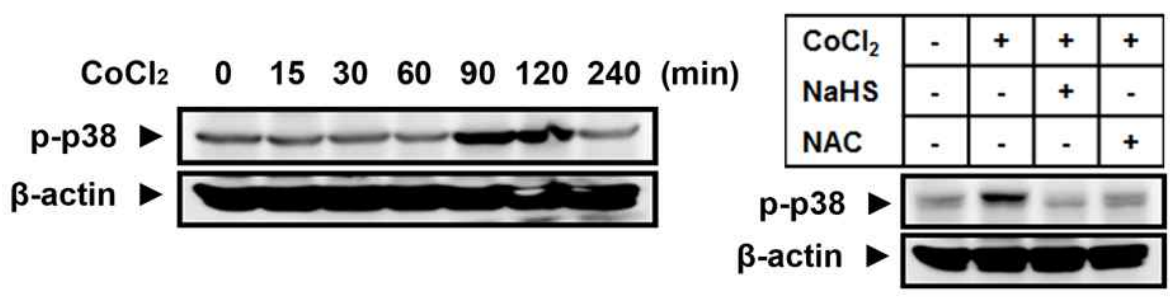

D

E
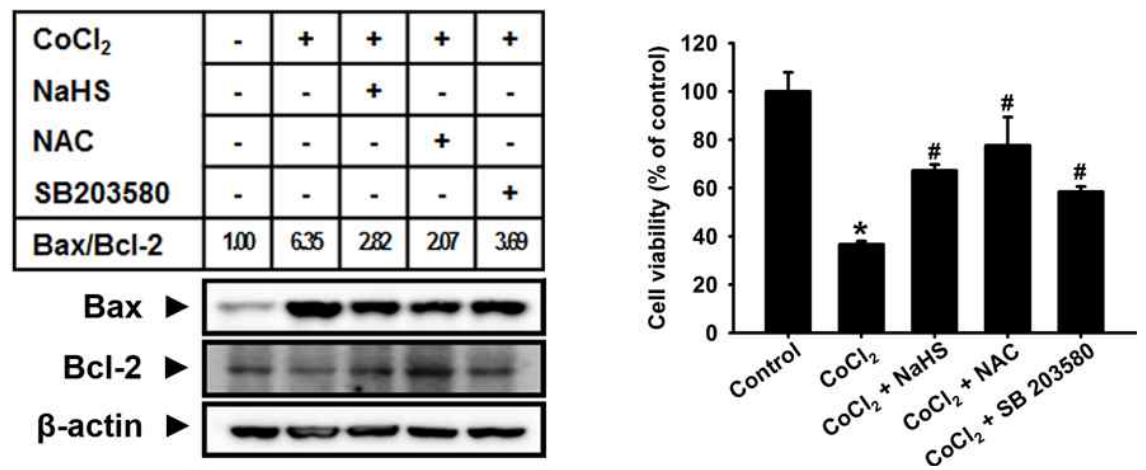

Fig. 3. Effect of $\mathrm{H}_{2} \mathrm{~S}$ on the $\mathrm{CoCl}_{2}$-induced ROS generation, p38 MAPK activation, and cell injury. (A) Dichlorofluorescein (DCF)sensitive cellular ROS was assessed. (a) Control. (b) Treatment with $500 \mu \mathrm{M} \mathrm{CoCl}_{2}$ for $2 \mathrm{~h}$ (c) Pretreatment with 1,000 $\mu \mathrm{M}$ NaHS for $30 \mathrm{~min}$ before exposure to $500 \mu \mathrm{M} \mathrm{CoCl} 2$ for $2 \mathrm{~h}$ (d) Pretreatment with 1,000 $\mu \mathrm{M} N$-acetyl-cysteine (NAC) for $30 \mathrm{~min}$ before exposure to $500 \mu \mathrm{M} \mathrm{CoCl}_{2}$ for $2 \mathrm{~h}$. (B) Cells were incubated for various times (0-240 min) with $500 \mu \mathrm{M} \mathrm{CoCl}_{2}$. (C) Cells were pretreated with $1,000 \mu \mathrm{M} \mathrm{NaHS}$ or 1,000 $\mu \mathrm{M}$ NAC for $30 \mathrm{~min}$ and then treated with $500 \mu \mathrm{M} \mathrm{CoCl}_{2}$ for 2 h. Cell lysates were subjected to western blotting to determine the levels of phospho-p38 MAPK. (D) Cells were pretreated with 1,000 $\mu \mathrm{M}$ NaHS, 1,000 $\mu \mathrm{M}$ NAC or $1 \mu \mathrm{M}$ SB 203580 (p38 MAPK inhibitor) for $30 \mathrm{~min}$ and then treated with $500 \mu \mathrm{M}$ $\mathrm{CoCl}_{2}$ for $12 \mathrm{~h}$. Cell lysates were subjected to western blotting to determine the levels of Bax and Bcl-2 expression and the Bax/Bcl-2 ratio was calculated. (E) Cells were pretreated 1,000 $\mu \mathrm{M}$ NaHS, 1,000 $\mu \mathrm{M}$ NAC, or $1 \mu \mathrm{M}$ SB 203580 for 30 min followed by incubation in the presence or absence of $500 \mu \mathrm{M} \mathrm{CoCl}_{2}$ for $12 \mathrm{~h}$. Cell viability was measured by CCK-8 assay. The values are expressed as the mean \pm SE of three independent experiments with triplicate dishes. ${ }^{*} \not<0.05$ vs. control, \# $p<0.05$ vs. $\mathrm{CoCl}_{2}$ only. 
A

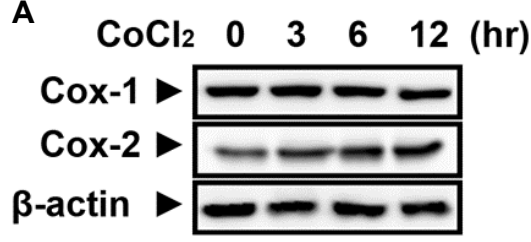

C

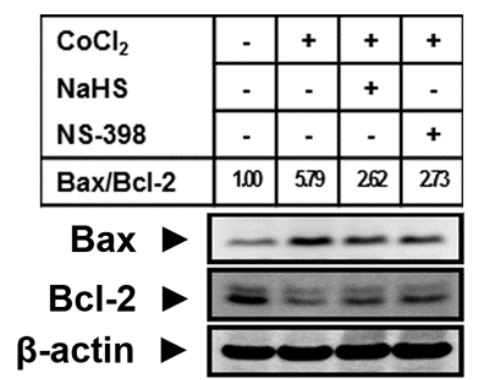

B

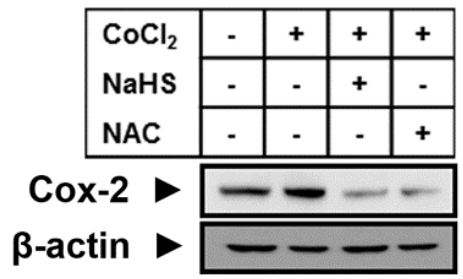

D

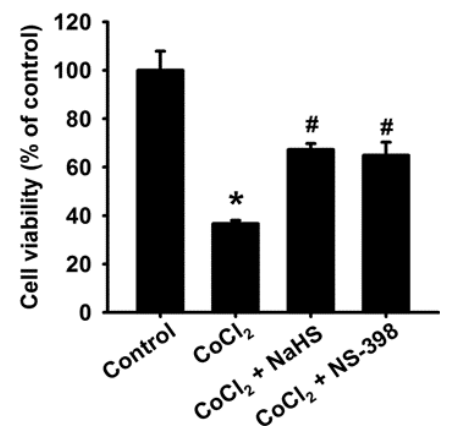

Fig. 4. Effect of $\mathrm{H}_{2} \mathrm{~S}$ on $\mathrm{CoCl}_{2}$-induced COX-2 expression and cell injury. (A) Mouse hepatocytes were incubated with $500 \mu \mathrm{M}$ CoCl 2 for various times $(0-24 \mathrm{~h})$. (B) Cells were pretreated with 1,000 $\mu \mathrm{M}$ NaHS or 1,000 $\mathrm{MM}$ NAC for 30 min and then treated with $500 \mu \mathrm{M} \mathrm{CoCl} 2$ for $12 \mathrm{~h}$. Cell lysates were subjected to western blotting to determine the level of COX-2 expression. (C) Cells were pretreated with 1,000 $\mu \mathrm{M}$ NaHS or $10 \mu \mathrm{M}$ NS-398 (COX-2 inhibitor) for 30 min and then treated with 500 $\mu \mathrm{M} \mathrm{CoCl} 2$ for $12 \mathrm{~h}$. Cell lysates were subjected to western blotting to determine the levels of Bax and Bcl-2 expression and the Bax/Bcl-2 ratio was calculated. (D) Cells were pretreated 1,000 $\mu \mathrm{M}$ NaHS or $10 \mu \mathrm{M}$ NS-398 for 30 min followed by incubation in the presence or absence of $500 \mu \mathrm{M} \mathrm{CoCl} 2$ for $12 \mathrm{~h}$. Cell viability was measured by CCK- 8 assay. The values are expressed as the mean $\pm \mathrm{SE}$ of three independent experiments with triplicate dishes. ${ }^{*} p<0.05$ vs. control, ${ }^{\#} p<0.05$ vs. $\mathrm{CoCl}_{2}$ only.

\section{Effect of $\mathrm{H}_{2} \mathrm{~S}$ on $\mathrm{CoCl}_{2}$-induced COX-2 expression}

After treatment of mosue hepatocytes with $\mathrm{CoCl}_{2}$, COX-2 expression was significantly augmented, while COX-1 expression was not significantly changed (Fig. 4A). Pretreatment with different concentrations of NaHS and NAC markedly attenuated the increased COX-2 expression by $\mathrm{CoCl}_{2}$ (Fig. 4B). We observed that pretreatment with NaHS or NS-398 (a selective COX-2 inhibitor, $10 \mu \mathrm{M}$ ) obviously inhibited the $\mathrm{CoCl}_{2}$-induced decrease of $\mathrm{Bcl}-2$ expression and increase of Bax expression and increase of Bax/Bcl-2 ratio by $\mathrm{CoCl}_{2}$ treatment was significantly decreased by $\mathrm{NaHS}$ or NS-398 (Fig. 4C). In addition, decreased cell viability by $\mathrm{CoCl}_{2}$ was partially recovered by pretreatment with $\mathrm{NaHS}$ or NS-398 (Fig. 4D).

\section{Discussion}

Hydrogen sulfide $\left(\mathrm{H}_{2} \mathrm{~S}\right)$, an endogenous gaseous mediator, exerts various physiological a pathophysiological effects in vivo, including anti-oxidative or anti-inflammatory effects in heart, liver, kidney and other organs [3, 13, 22, 49]. Although $\mathrm{H}_{2} \mathrm{~S}$ has long been considered as a toxic environ- mental pollutant emerging from sewers, marshes, and volcanic eruptions, $\mathrm{H}_{2} \mathrm{~S}$ has been recently recognized along-side nitric oxide and carbon monoxide as an endogenously produced gaseous signaling molecule [22, 33, 47]. Previous studies suggested that $\mathrm{H}_{2} \mathrm{~S}$ is a potent antioxidant $[27,60]$ and it has also been demonstrated that $\mathrm{H}_{2} \mathrm{~S}$ effectively inhibits apoptosis of a number of cell types [12, 39, 44] and this effect has been shown to promote cytoprotection. Cobalt chloride $\left(\mathrm{CoCl}_{2}\right)$ has been reported to take the place of ferrous ions in prolyl-4-hydroxylase $(\mathrm{P} 4 \mathrm{H})$, thereby causing a conformational change in the $\mathrm{P} 4 \mathrm{H}$ protein that consequently leads to a hypoxic condition, characterized by intranuclear accumulation of hypoxia inducible factor-1a (HIF-1a) [15, 42, 61]. $\mathrm{CoCl}_{2}$ has been also known to induce apoptosis in various types of cells $[16,29,48]$. In the current study, we demonstrated that chemical hypoxia-induced hepatocellular injury is markedly decreased by sodium hydrosulfide (NaHS, a donor of $\mathrm{H}_{2} \mathrm{~S}$ ). The exposure of mouse hepatocytes to $\mathrm{CoCl}_{2}$ induced cytotoxicity, evidenced by the decreased cell viability, and we observed that NaHS significantly attenuated $\mathrm{CoCl}_{2}$-induced decrease of cell viability. These results indicate that hydrogen sulfide $\left(\mathrm{H}_{2} \mathrm{~S}\right)$ plays a role in suppress- 
ing cell death induced by chemical hypoxia.

It has been known that hypoxia or hypoxia-mimicking $\mathrm{CoCl}_{2}$-induced injury is mediated by the generation of reactive oxygen species (ROS) [17, 65]. In general, overproduction of ROS induced by oxidative stress may cause oxidative damage to DNA, lipids and proteins, resulting in apoptosis of cells including hepatocytes [25, 31]. In this study, exposure of mouse hepatocytes to $\mathrm{CoCl}_{2}$ increased intracellular ROS and $\mathrm{CoCl}_{2}$-induced ROS generations were attenuated by pretreatment of $\mathrm{NaHS}$ or $\mathrm{N}$-acetylcystein (NAC), a common ROS scavenger. These results show that $\mathrm{H}_{2} \mathrm{~S}$ possesses scavenging activity of ROS, which induced by $\mathrm{CoCl}_{2}$. Indeed, Geng et al. reported that $\mathrm{H}_{2} \mathrm{~S}$ directly scavenges superoxide anions and $\mathrm{H}_{2} \mathrm{O}_{2}$ [14]. Recent studies have demonstrated that ROS are important triggers to upregulate p38 MAPK activity and that antioxidants can be consequently applied to inhibit p38 activation $[8,30,65]$. In hepatocytes, the p38 signaling pathway is preferentially activated by inflammatory cytokines and various stresses, such as UV light or hypoxia [2, 31, 38, 54]. ROS also can activate p38 pathway $[19,31,63]$. In accordance with previous reports, our results showed that NaHS or NAC attenuated $\mathrm{CoCl}_{2}$-induced p38 MAPK activation. These results suggest that $\mathrm{H}_{2} \mathrm{~S}$ blocks p38 MAPK through its antioxidant effect. Various studies have demonstrated that $\mathrm{CoCl}_{2}$ elicits oxidative stress, which constibutes to apoptosis in other cell types [30, 57, 65]. Additionally, oxidative stress-induced p38 MAPK activation was involved in hepatocyte injury [1, 20, 45]. This is supported by our results in which $\mathrm{CoCl}_{2}$-induced cytotoxicity was prevented by NaHS, NAC, and SB 203580 (a p38 MAPK inhibitor) treatment. In addition, NaHS, NAC, and SB 203580 blocked the $\mathrm{CoCl}_{2}$-induced increase of $\mathrm{Bax} / \mathrm{Bcl}-2$ ratio. Of the Bcl-2 family of proteins, including $\mathrm{Bcl}-2$ and Bcl2-related family members such as Bcl-xL, Bad and Bax, play an important role in the regulation of apoptosis [41]. In the present study, we showed that pretreatment of mouse hepatocytes with NaHS, NAC, and SB 203580 resulted in a significant decrease of increased expression of Bax, a proapoptotic Bcl-2 family member and potentiation of decreased expression of Bcl-2, an antiapoptotic Bcl-2 family member, by $\mathrm{CoCl}_{2}$. Therefore, our results suggest that $\mathrm{H}_{2} \mathrm{~S}$ pretreatment plays a cytoprotective role via attenuation not only of $\mathrm{CoCl}_{2}$-induced ROS, but also of p38 MAPK activated by $\mathrm{CoCl}_{2}$-induced $\mathrm{ROS}$.

Our current study showed that exposure of mouse hepatocytes to $\mathrm{CoCl}_{2}$ elevated expression of COX-2. At present,
COX is classified by at least two forms [24, 43]. COX-1 is constitutively expressing form, while COX-2 is induced by multiple factors including cytokines, hormones, mitogens, oxidative stresses, and so forth. In our results, enhanced COX-2 expression by $\mathrm{CoCl}_{2}$ was suppressed by the pretreatment with NaHS and NAC. This result indicates that COX-2 expression is enhanced by $\mathrm{CoCl}_{2}$-induced intracellular ROS and $\mathrm{H}_{2} \mathrm{~S}$ represses COX-2 expression by its antioxidant activity. Previous studies showed that inhibition of COX-2 exerts hepatoprotective effects on liver damage [51]. COX-2 expression is upregulated by ischemia or reperfusion in the rat liver, and the inhibition of COX-2 is found to improve liver function and viability $[26,35]$. Through this study, we observed that NaHS and NS-398, a selective inhibitor of COX-2, significantly attenuated $\mathrm{CoCl}_{2}$-induced increase of $\mathrm{Bax} / \mathrm{Bcl}-2$ ratio. In addition, NaHS and NS-398 attenuated $\mathrm{CoCl}_{2}$-induced cytotoxicity. Overall, these findings suggest that oxidative stress plays a pivotal role in hepatocellular injuries induced by $\mathrm{CoCl}_{2}$ and $\mathrm{ROS}$ mediate $\mathrm{CoCl}_{2}$-induced injury through p38 MAPK and COX-2 pathway in mouse hepatocytes. In conclusion, the present study demonstrated that $\mathrm{H}_{2} \mathrm{~S}$ has a cytoprotective effect against chemical hypoxia-induced cell injury through inhibition of the ROS, p38 MAPK, and COX-2 pathway in primary cultured mouse hepatocytes.

\section{Acknowledgement}

This research was supported by Kyungpook National University Research Fund, 2012.

\section{References}

1. Bhattacharyya, S., Pal, P. B. and Sil, P. C. 2013. A 35 kD Phyllanthus niruri protein modulates iron mediated oxidative impairment to hepatocytes via the inhibition of ERKs, p38 MAPKs and activation of PI3k/Akt pathway. Food Chem Toxicol 56, 119-130.

2. Bhogal, R. H., Weston, C. J., Curbishley, S. M., Adams, D. H. and Afford, S. C. 2012. Activation of CD40 with platelet derived CD154 promotes reactive oxygen species dependent death of human hepatocytes during hypoxia and reoxygenation. PLOS One 7, e30867.

3. Bian, J. S., Yong, Q. C., Pan, T. T., Feng, Z. N., Ali, M. Y., Zhou, S. and Moore, P. K. 2006. Role of hydrogen sulfide in the cardioprotection caused by ischemic preconditioning in the rat heart and cardiac myocytes. J Pharmacol Exp Ther 316, 670-678.

4. Booth, E. A., Flint, R. R., Lucas, K. L., Knittel, A. K. and 
Lucchesi, B. R. 2008. Estrogen protects the heart from ischemia-reperfusion injury via COX-2-derived PGI2. J Cardiovasc Pharmacol 52, 228-235.

5. Bredesen, D. E., Rao, R. V. and Mehlen, P. 2006. Cell death in the nervous system. Nature 443, 796-802.

6. Calvert, J. W., Coetzee, W. A. and Lefer, D. J. 2010. Novel insights into hydrogen sulfide-mediated cytoprotection. Antioxid Redox Signal 12, 1203-1217.

7. Carnieto, A., Jr., Dourado, P. M., Luz, P. L. and Chagas, A. C. 2009. Selective cyclooxygenase-2 inhibition protects against myocardial damage in experimental acute ischemia. Clinics (Sao Paulo) 64, 245-252.

8. Chen, L., Liu, L. and Huang, S. 2008. Cadmium activates the mitogen-activated protein kinase (MAPK) pathway via induction of reactive oxygen species and inhibition of protein phosphatases 2A and 5. Free Radic Biol Med 45, 10351044.

9. Cheng, Y., Ndisang, J. F., Tang, G., Cao, K. and Wang, R. 2004. Hydrogen sulfide-induced relaxation of resistance mesenteric artery beds of rats. Am J Physid Heart Circ Physid 287, H2316-2323.

10. Cindrova-Davies, T., Spasic-Boskovic, O., Jauniaux, E., Charnock-Jones, D. S. and Burton, G. J. 2007. Nuclear factor-kappa B, p38, and stress-activated protein kinase mitogen-activated protein kinase signaling pathways regulate proinflammatory cytokines and apoptosis in human placental explants in response to oxidative stress: effects of antioxidant vitamins. Am J Pathol 170, 1511-1520.

11. Dupouy, V. M., Ferre, P. J., Uro-Coste, E. and Lefebvre, H. P. 2006. Time course of COX-1 and COX-2 expression during ischemia-reperfusion in rat skeletal muscle. J Appl Physiol 100, 233-239.

12. Elrod, J. W., Calvert, J. W., Morrison, J., Doeller, J. E., Kraus, D. W., Tao, L., Jiao, X., Scalia, R., Kiss, L., Szabo, C., Kimura, H., Chow, C. W. and Lefer, D. J. 2007. Hydrogen sulfide attenuates myocardial ischemia-reperfusion injury by preservation of mitochondrial function. Proc Natl Acad Sci USA 104, 15560-15565.

13. Fiorucci, S., Antonelli, E., Mencarelli, A., Orlandi, S., Renga, B., Rizzo, G., Distrutti, E., Shah, V. and Morelli, A. 2005. The third gas: $\mathrm{H} 2 \mathrm{~S}$ regulates perfusion pressure in both the isolated and perfused normal rat liver and in cirrhosis. Hepatology 42, 539-548.

14. Geng, B., Chang, L., Pan, C., Qi, Y., Zhao, J., Pang, Y., Du, J. and Tang, C. 2004. Endogenous hydrogen sulfide regulation of myocardial injury induced by isoproterenol. Biochem Biophys Res Commun 318, 756-763.

15. Goldberg, M. A., Dunning, S. P. and Bunn, H. F. 1988. Regulation of the erythropoietin gene: evidence that the oxygen sensor is a heme protein. Science 242, 1412-1415.

16. Gotoh, M., Sano-Maeda, K., Murofushi, H. and MurakamiMurofushi, K. 2012. Protection of neuroblastoma Neuro2A cells from hypoxia-induced apoptosis by cyclic phosphatidic acid (cPA). PLoS One 7, e51093.

17. Guillemin, K. and Krasnow, M. A. 1997. The hypoxic response: huffing and HIFing. Cell 89, 9-12.
18. Guo, M., Song, L. P., Jiang, Y., Liu, W., Yu, Y. and Chen, G. Q. 2006. Hypoxia-mimetic agents desferrioxamine and cobalt chloride induce leukemic cell apoptosis through different hypoxia-inducible factor-1alpha independent mechanisms. Apoptosis 11, 67-77.

19. Herrera, B., Fernandez, M., Roncero, C., Ventura, J. J., Porras, A., Valladares, A., Benito, M. and Fabregat, I. 2001. Activation of p38 MAPK by TGF-beta in fetal rat hepatocytes requires radical oxygen production, but is dispensable for cell death. FEBS Lett 499, 225-229.

20. Hyun, M. S., Hur, J. M., Mun, Y. J., Kim, D. and Woo, W. H. 2010. BBR induces apoptosis in HepG2 cell through an Akt-ASK1-ROS-p38 MAPKs-linked cascade. J Cell Biochem 109, 329-338.

21. Ito, Y., Katagiri, H., Ishii, K., Kakita, A., Hayashi, I. and Majima, M. 2003. Effects of selective cyclooxygenase inhibitors on ischemia/reperfusion-induced hepatic microcirculatory dysfunction in mice. Eur Surg Res 35, 408-416.

22. Jha, S., Calvert, J. W., Duranski, M. R., Ramachandran, A. and Lefer, D. J. 2008. Hydrogen sulfide attenuates hepatic ischemia-reperfusion injury: role of antioxidant and antiapoptotic signaling. Am J Physiol Heart Circ Physiol 295, H801-806.

23. Jung, J. Y., Mo, H. C., Yang, K. H., Jeong, Y. J., Yoo, H. G., Choi, N. K., Oh, W. M., Oh, H. K., Kim, S. H., Lee, J. H., Kim, H. J. and Kim, W. J. 2007. Inhibition by epigallocatechin gallate of $\mathrm{CoCl} 2$-induced apoptosis in rat $\mathrm{PC12}$ cells. Life Sci 80, 1355-1363.

24. Jung, W. K., Heo, S. J., Jeon, Y. J., Lee, C. M., Park, Y. M., Byun, H. G., Choi, Y. H., Park, S. G. and Choi, I. W. 2009. Inhibitory effects and molecular mechanism of dieckol isolated from marine brown alga on COX-2 and iNOS in microglial cells. J Agric Food Chem 57, 4439-4446.

25. Karimian, G., Buist-Homan, M., Mikus, B., Henning, R. H., Faber, K. N. and Moshage, H. 2012. Angiotensin II protects primary rat hepatocytes against bile salt-induced apoptosis. PLOS One 7, e52647.

26. Kim, H. J., Yang, S. J., Kim, Y. S. and Kim, T. U. 2003. Cobalt chloride-induced apoptosis and extracellular signal-regulated protein kinase activation in human cervical cancer HeLa cells. J Biochem Mol Biol 36, 468-474.

27. Kimura, Y. and Kimura, H. 2004. Hydrogen sulfide protects neurons from oxidative stress. FASEB J 18, 1165-1167.

28. Kwak, H. J., Park, K. M., Choi, H. E., Lim, H. J., Park, J. H. and Park, H. Y. 2010. The cardioprotective effects of zileuton, a 5-lipoxygenase inhibitor, are mediated by COX-2 via activation of PKC delta. Cell Signal 22, 80-87.

29. Lan, A., Xu, W., Zhang, H., Hua, X., Zheng, D., Guo, R., Shen, N., Hu, F., Feng, J. and Liu, D. 2013. Inhibition of ROS-activated p38 MAPK pathway is involved in the protective effect of H2S against chemical hypoxia-induced inflammation in PC12 cells. Neurochem Res 38, 1454-1466.

30. Lan, A. P., Xiao, L. C., Yang, Z. L., Yang, C. T., Wang, X. Y., Chen, P. X., Gu, M. F. and Feng, J. Q. 2012. Interaction between ROS and p38 MAPK contributes to chemical hypoxia-induced injuries in PC12 cells. Mol Med Rep 5, 250-255. 
31. Lee, M. Y., Jung, S. C., Lee, J. H. and Han, H. J. 2008. Estradiol-17beta protects against hypoxia-induced hepatocyte injury through ER-mediated upregulation of Bcl-2 as well as ER-independent antioxidant effects. Cell Res 18, 491-499.

32. Leffler, C. W., Parfenova, H., Jaggar, J. H. and Wang, R. 2006. Carbon monoxide and hydrogen sulfide: gaseous messengers in cerebrovascular circulation. J Appl Physiol 100, 1065-1076

33. Lichtman, S. N. and Lemasters, J. J. 1999. Role of cytokines and cytokine-producing cells in reperfusion injury to the liver. Semin Liver Dis 19, 171-187.

34. Nakanishi, K., Tajima, F., Nakamura, A., Yagura, S., Ookawara, T., Yamashita, H., Suzuki, K., Taniguchi, N. and Ohno, H. 1995. Effects of hy pobaric hypoxia on antioxidant enzymes in rats. $J$ Physiol 489, 869-876.

35. Oshima, K., Yabata, Y., Yoshinari, D. and Takeyoshi, I. 2009. The effects of cyclooxygenase (COX)-2 inhibition on ischemia-reperfusion injury in liver transplantation. J Invest Surg 22, 239-245.

36. Pae, H. O., Lee, Y. C., Jo, E. K. and Chung, H. T. 2009. Subtle interplay of endogenous bioactive gases (NO, CO and $\mathrm{H}(2) \mathrm{S})$ in inflammation. Arch Pharm Res 32, 1155-1162.

37. Pearson, G., Robinson, F., Beers Gibson, T., Xu, B. E., Karandikar, M., Berman, K. and Cobb, M. H. 2001. Mitogenactivated protein (MAP) kinase pathways: regulation and physiological functions. Endocr Rev 22, 153-183.

38. Quiroga, A. D., de Lujan Alvarez, M., Parody, J. P., Ronco, M. T., Carnovale, C. E. and Carrillo, M. C. 2009. Interferonalpha2b (IFN-alpha2b)-induced apoptosis is mediated by p38 MAPK in hepatocytes from rat preneoplastic liver via activation of NADPH oxidase. Growth Factors 27, 214-227.

39. Rose, P., Moore, P. K., Ming, S. H., Nam, O. C., Armstrong, J. S. and Whiteman, M. 2005. Hydrogen sulfide protects colon cancer cells from chemopreventative agent beta-phenylethyl isothiocyanate induced apoptosis. World J Gastroenterd 11, 3990-3997.

40. Roulston, A., Reinhard, C., Amiri, P. and Williams, L. T. 1998. Early activation of c-Jun N-terminal kinase and p38 kinase regulate cell survival in response to tumor necrosis factor alpha. J Biol Chem 273, 10232-10239.

41. Sarada, S. K., Himadri, P., Ruma, D., Sharma, S. K., Pauline, T. and Mrinalini. 2008. Selenium protects the hypoxia induced apoptosis in neuroblastoma cells through upregulation of Bcl-2. Brain Res 1209, 29-39.

42. Sharp, F. R. and Bernaudin, M. 2004. HIF1 and oxygen sensing in the brain. Nat Rev Neurosci 5, 437-448.

43. Smith, W. L., DeWitt, D. L. and Garavito, R. M. 2000. Cyclooxygenases: structural, cellular, and molecular biology. Annu Rev Biochem 69, 145-182.

44. Sodha, N. R., Clements, R. T., Feng, J., Liu, Y., Bianchi, C., Horvath, E. M., Szabo, C. and Sellke, F. W. 2008. The effects of therapeutic sulfide on myocardial apoptosis in response to ischemia-reperfusion injury. Eur J Cardiothorac Surg 33, 906-913.

45. Song, M. K., Kim, Y. J., Song, M., Choi, H. S., Park, Y. K. and Ryu, J. C. 2011. Polycyclic aromatic hydrocarbons induce migration in human hepatocellular carcinoma cells (HepG2) through reactive oxygen species-mediated p38 MAPK signal transduction. Cancer Sci 102, 1636-1644.

46. Swaroop, M., Bradley, K., Ohura, T., Tahara, T., Roper, M. D., Rosenberg, L. E. and Kraus, J. P. 1992. Rat cystathionine beta-synthase. Gene organization and alternative splicing. J Biol Chem 267, 11455-11461.

47. Szabo, C. 2007. Hydrogen sulphide and its therapeutic potential. Nat Rev Drug Discov 6, 917-935.

48. Talwar, S., Jin, J., Carroll, B., Liu, A., Gillespie, M. B. and Palanisamy, V. 2011. Caspase-mediated cleavage of RNAbinding protein $\mathrm{HuR}$ regulates $\mathrm{c}-\mathrm{Myc}$ protein expression after hypoxic stress. J Biol Chem 286, 32333-32343.

49. Tripatara, P., Patel, N. S., Brancaleone, V., Renshaw, D., Rocha, J., Sepodes, B., Mota-Filipe, H., Perretti, M. and Thiemermann, C. 2009. Characterisation of cystathionine gamma-lyase/hydrogen sulphide pathway in ischaemia/reperfusion injury of the mouse kidney: an in vivo study. Eur $J$ Pharmacol 606, 205-209.

50. Tu, X. K., Yang, W. Z., Shi, S. S., Wang, C. H. and Chen, C. M. 2009. Neuroprotective effect of baicalin in a rat model of permanent focal cerebral ischemia. Neurochem Res 34, 1626-1634.

51. Vadiraja, B. B., Gaikwad, N. W. and Madyastha, K. M. 1998. Hepatoprotective effect of C-phycocyanin: protection for carbon tetrachloride and R-(+)-pulegone-mediated hepatotoxicty in rats. Biochem Biophys Res Commun 249, 428-431.

52. Valko, M., Leibfritz, D., Moncol, J., Cronin, M. T., Mazur, M. and Telser, J. 2007. Free radicals and antioxidants in normal physiological functions and human disease. Int $J$ Biochem Cell Biol 39, 44-84.

53. Wallace, J. L. 2010. Physiological and pathophysiological roles of hydrogen sulfide in the gastrointestinal tract. Antioxid Redox Signal 12, 1125-1133.

54. Werwein, E., Dzuganova, M., Usadel, C. and Klempnauer, K. H. 2013. B-Myb switches from Cyclin/Cdk-dependent to Jnk- and p38 kinase-dependent phosphorylation and associates with SC35 bodies after UV stress. Cell Death Dis 4, e511.

55. Xia, Z., Dickens, M., Raingeaud, J., Davis, R. J. and Greenberg, M. E. 1995. Opposing effects of ERK and JNK-p38 MAP kinases on apoptosis. Science 270, 1326-1331.

56. Yang, C., Ling, H., Zhang, M., Yang, Z., Wang, X., Zeng, F., Wang, C. and Feng, J. 2011. Oxidative stress mediates chemical hypoxia-induced injury and inflammation by activating NF-kappab-COX-2 pathway in HaCaT cells. $M d$ Cells 31, 531-538.

57. Yang, C., Yang, Z., Zhang, M., Dong, Q., Wang, X., Lan, A., Zeng, F., Chen, P., Wang, C. and Feng, J. 2011. Hydrogen sulfide protects against chemical hypoxia-induced cytotoxicity and inflammation in $\mathrm{HaCaT}$ cells through inhibition of ROS/NF-kappaB/COX-2 pathway. PLoS One 6, e21971.

58. Yeo, J. E., Kim, J. H. and Kang, S. K. 2008. Selenium attenuates ROS-mediated apoptotic cell death of injured spinal cord through prevention of mitochondria dysfunction; in vi- 
tro and in vivo study. Cell Physiol Biochem 21, 225-238.

59. Yokoyama, C. and Tanabe, T. 1989. Cloning of human gene encoding prostaglandin endoperoxide synthase and primary structure of the enzyme. Biochem Biophys Res Commun $165,888-894$.

60. Yonezawa, D., Sekiguchi, F., Miyamoto, M., Taniguchi, E., Honjo, M., Masuko, T., Nishikawa, H. and Kawabata, A. 2007. A protective role of hydrogen sulfide against oxidative stress in rat gastric mucosal epithelium. Toxicology 241, 11-18.

61. Yuan, Y., Hilliard, G., Ferguson, T. and Millhorn, D. E. 2003. Cobalt inhibits the interaction between hypoxia-inducible factor-alpha and von Hippel-Lindau protein by direct binding to hypoxia-inducible factor-alpha. J Biol Chem 278, 15911-15916.

62. Yun, Y., Duan, W. G., Chen, P., Wu, H. X., Shen, Z. Q.,
Qian, Z. Y. and Wang, D. H. 2009. Down-regulation of cyclooxygenase-2 is involved in ischemic postconditioning protection against renal ischemia reperfusion injury in rats. Transplant Proc 41, 3585-3589.

63. Zhang, Y., Qi, X., Gong, L., Li, Y., Liu, L., Xue, X., Xiao, $\mathrm{Y} ., \mathrm{Wu}, \mathrm{X}$. and Ren, J. 2008. Roles of reactive oxygen species and MAP kinases in the primary rat hepatocytes death induced by toosendanin. Toxicology 249, 62-68.

64. Zou, W., Yan, M., Xu, W., Huo, H., Sun, L., Zheng, Z. and Liu, X. 2001. Cobalt chloride induces PC12 cells apoptosis through reactive oxygen species and accompanied by AP-1 activation. J Neurosci Res 64, 646-653.

65. Zou, W., Zeng, J., Zhuo, M., Xu, W., Sun, L., Wang, J. and Liu, X. 2002. Involvement of caspase- 3 and p38 mitogenactivated protein kinase in cobalt chloride-induced apoptosis in PC12 cells. J Neurosci Res 67, 837-843.

초록 : 화학적 허혈에 의해 손상된 마우스 간세포에 대한 hydrogen sulfide의 간세포 보호 효과

이민영*

(경북대학교 약학대학 약학과 분자생리학 연구실)

본 연구는 화학적 허혈에 의해 손상된 마우스 간세포에서 hydrogen sulfide $\left(\mathrm{H}_{2} \mathrm{~S}\right)$ 의 효과를 규명하기 위해 수행 되었다. 본 연구에서 허혈 모방 화합물로 알려져 있는 cobalt chloride $\left(\mathrm{CoCl}_{2}\right)$ 는 간세포 손상을 시간 및 농도 의존 적으로 유의성 있게 증가 시켰다. $\mathrm{CoCl}_{2}$ 에 의한 간세포 손상은 Sodium sulfide $\left(\mathrm{NaHS}, \mathrm{H}_{2} \mathrm{~S}\right.$ 공여제)의 전처리에 의해 유의적으로 감소 되었다. $\mathrm{CoCl}_{2}$ 는 세포 내 활성산소(reactive oxygen species, $\mathrm{ROS}$ )의 농도를 증가시켰으며, 이는 NaHS 및 $N$-acetyl-cysteine (NAC, a ROS 제거제)에 의해 감소하였다. 또한, $\mathrm{CoCl}_{2}$ 에 의해 증가된 $\mathrm{p} 38$ $\mathrm{MAPK}$ 인산화가 $\mathrm{NaHS}$ 및 NAC에 의해 억제되었다. $\mathrm{CoCl}_{2}$ 에 의해 증가된 $\mathrm{Bax} / \mathrm{Bcl}-2$ 비율은 $\mathrm{NaHS}, \mathrm{NAC}$ 및 $\mathrm{SB}$ 203580 (p38 MAPK 저해제)에 의해 차단되었으며, $\mathrm{CoCl}_{2}$ 에 의해 유발된 간세포의 손상 또한 $\mathrm{NaHS}, \mathrm{NAC}$ 및 SB 203580 의 전처리에 의해 억제되었다. $\mathrm{NaHS}$ 는 $\mathrm{CoCl}_{2}$ 에 의해 증가된 $\mathrm{COX}-2$ 의 발현을 억제하였다. 또한, $\mathrm{NaHS}$ 의 효과와 유사하게 $\mathrm{CoCl}_{2}$ 에 의해 증가된 COX-2의 발현이 NAC에 의해 억제되었다. 더욱이, NS-398 (COX-2 선택적 억제제)는 $\mathrm{CoCl}_{2}$ 에 의한 $\mathrm{Bax} / \mathrm{Bcl}-2$ 비율의 증가를 억제하였을 뿐 아니라, 간세포의 세포 손상 또한 억제하였다. 결론적으로, $\mathrm{H}_{2} \mathrm{~S}$ 는 초대배양 된 마우스 간세포에서 $\mathrm{CoCl}_{2}$ 에 의해 유발된 간세포의 손상을 $\mathrm{ROS}$ 에 의해 유발된 p38 MAPK 및 COX-2 경로의 활성화를 억제함으로써 세포보호효과를 수행하는 것을 알 수 있었다. 